\title{
Los cortejos del diablo: Lo cómico del poder inquisitorial ${ }^{1}$
}

reflection article

\section{The courtship of the devil: The comic of the inquisitorial power}

\section{Hernando Motato $C .{ }^{2}$ \\ Universidad Industrial de Santander, Colombia \\ (i) https://orcid.org/0000-0002-5122-6291}

\section{Hugo Armando Arciniegas 3 Universidad Industrial de Santander, Colombia \\ (iD) https://orcid.org/0000-0002-5643-0128}

Resumen: En este artículo reflexionamos sobre lo cómico de la novela Los cortejos del diablo (1970), del autor colombiano Germán Espinosa, a partir del papel que desempeñan la locura del inquisidor, Juan de Mañozga, y la degradación a la que sus áulicos y sirvientes lo someten. Para ello, establecemos un análisis contrastivo entre los planos ficcional e histórico, con base en planteamientos en torno a lo cómico tomados de Baudelaire, Bergson y Bajtín. Los aspectos cómicos que pierden a Mañozga, y que se asocian con brujas y demonios, justifican la presencia del inquisidor en la ciudad de Cartagena, así como el propósito de la Inquisición.

Palabras clave: cómico; Inquisición; ficción; historia; demoniaco

Recibido: 27/07/2019 | Aceptado: 23/01/2020 | Disponible en línea: 30/04/2020

Como citar este artículo: Motato C., H. y Arciniegas, H. (2020). Los cortejos del diablo: Lo cómico del poder inquisitorial. Jangwa Pana, 19(1), 284 - 296. Doi: https://doi.org/10.21676/16574923.3475

Abstract: In this article we reflect on the comic aspect in the novel Los cortejos del diablo (1970), by the Colombian author Germán Espinosa, based on the role played by the inquisitor's madness, Juan de Mañozga, and the degradation he is subjected to by his aulics and servants. To do this, we establish a contrastive analysis between the fictional and historical levels, according to some approaches regarding to the comic aspect proposed by Baudelaire, Bergson, and Bakhtin. The comic aspects that demean Mañozga, and that are associated with witches and demons, justify the presence of the inquisitor in the city of Cartagena, as well as the purpose of the Inquisition.

Key words: comic; Inquisition; fiction; history; demonic

\footnotetext{
${ }^{1}$ Los autores declaramos que no tenemos conflicto de intereses con la revista, que pertenecemos al grupo de investigación Glotta, de la Escuela de Idiomas UIS, que este proyecto no cuenta con financiación institucional y que la ejecución del trabajo y la redacción del manuscrito se realizaron con interés concerniente al ejercicio investigativo.

${ }^{2}$ Correo electrónico: jhmotato@yahoo.com

${ }^{3}$ Correo electrónico: hugo.arciniegas@ correo.uis.edu.co
} 


\section{Introducción}

Tres claves comprenden la esencia de este artículo. La primera concierne al sentido histórico de la trama de Los cortejos del diablo. Esta novela de Germán Espinosa se publica en pleno esplendor del boom, cuando los representantes de esta generación están comprometidos a sostener su reconocimiento internacional. Espinosa escribe una obra magistral a partir de un manejo excepcional del lenguaje y del recurso de lo cómico, en la que se narra la presencia de la Inquisición en la colonial Cartagena. Para ello, el escritor retoma el nombre del inquisidor Juan de Mañozga y Zamora, nacido en Vizcaya, España:

El 21 de diciembre de 1610, el Inquisidor General y el Supremo y General Consejo de la Inquisición se establecieron formalmente en la Cartagena de Indias, el Tribunal Inquisitorial y señalaban los territorios que quedaban dentro de la jurisdicción [...] Las personas que conformaron el primer equipo inquisitorial y el Tribunal de Cartagena fueron los licenciados Juan de Mañozga y Pedro Mateo de Salcedo, inquisidores. Francisco Bazán de Albornoz ocupó el cargo de fiscal y Luis Blanco de Salcedo el de notario del secreto. Estos llegaron a Cartagena el 21 de diciembre de 1610 (Rosas, 2010: 54).

A partir de dicho año Mañozga empieza a cumplir su oficio, el de inquisidor, de la manera más tirana. No solo persigue a cristianos nuevos o judíos no declarados - como es el caso del personaje Spinoza, en esta novela-, sino también a los esclavos sindicados de prácticas de brujería. Este hombre, graduado en Letras de la Universidad de México, tiene una cultura extremada en los odios contra las personas que no son de su misma condición social o de su color, tal como lo experimenta con los indios en México. Asimismo, cuando llega a Cartagena su vida se le hace insoportable debido al calor y sopor de la ciudad y, sobre todo, a las expresiones de algarabía y desparpajo sexual de los negros. La estadía en esta ciudad portuaria es solo un fin para el ascenso a las altas jerarquías de la Iglesia católica, pero allí encuentra otra realidad, así como exclama en medio de las tribulaciones de su soledad:

¡Madre, qué calor! ¡Mueren los bueyes de tanta peste! ¡Y es epidemia de brujos, multiplicación, proliferación gigantesca y monstruosa de brujos batiendo sobre los tejados alas membranosas, alas de murciélagos, de vampiro, alas horribles, alas negras y felpudas sobre el convento de San Diego, el de Santa Teresa, el de Santa Clara, el de la Merced, sobre los legados de doña Catalina de Cabrera, sobre el colegio de la Compañía, sobre las Casas Reales, y la de la Moneda, sobre los fuertes de los Icacos y el de la Punta del Judío, sobre los novísimos bastiones enjalbegados de sangre de esclavos, sobre Santa Cruz, ay, sobre la misma santa cruz (Espinosa, 2006: 17).

Este soliloquio recorre cuidadosamente los espacios de la ciudad que allí se levantan desde la época colonial y que aún perduran como un culto a la memoria histórica. En su desmesura inquisitorial que le desencaja la cabeza y lo pone a hablar consigo mismo, aparecen los sitios de Cartagena, los enclaves religiosos, expresiones del dominio católico, y afuera, la ciudad de la población negra, con los prejuicios brujeriles con que se la asocia y que se conciben como la justificación del ejercicio del Tribunal Inquisitorial. 
Lo inquisitorial define Los cortejos del diablo a través de este hecho histórico, pero, en la medida en que transcurren los acontecimientos en torno a Juan de Mañozga, aparecen nuevos personajes por medio de los que la figura del inquisidor se degrada. La blanca y sensual Catalina de Alcántara, por ejemplo, le perturba su quietud y lo tienta a pensar en el sexo cuando se pasea desnuda por las oscuras calles de Cartagena. Luego aparece Lorenzo Spinoza, contra quien emprende una redada de conversos:

La gran redada de conversos que emprendió el Tribunal de la Inquisición de Cartagena entre 1630 y 1640, después se dedicó a acosar blasfemos, bígamos, solicitantes, sacrílegos, hechiceros y falsos testigos. También a quienes renegaban de la religión o emitían proposiciones heréticas. Aunque las persecuciones a los judaizantes no fueron olvidadas, su número decreció y los que osaban arrimar a las costas se expusieron a caer en manos de los inquisidores hacia la segunda mitad del siglo XVII (Navarrete, 2017: 136-137)

El inquisidor piensa que es esta su función esencial, ya que así nace la Inquisición en España: con el objeto de perseguir a los judíos y a todo aquel que atente contra los mandatos del catolicismo. El saber del filósofo atenta contra los estatutos de la fe, que son imperantes para el sometimiento a los indios y negros, pero estos últimos conservan sus prácticas ancestrales traídas de su lejana África.

Lo cierto es que se piensa que el diablo está en Cartagena de Indias y quince personas, la mayoría negras u horras, se ven directamente involucradas, por primera vez, o al menos de forma directa, se conocen los aquelarres en América, sin apenas variación alguna (Blázquez, 1994:73).

Así tenemos que la brujería, los diablos, las mujeres negras, el sexo, los judíos conversos y los bailes en la periferia de la ciudad mellan la estabilidad emocional y física de Juan de Mañozga. Poco a poco esa inestabilidad lacera su pensamiento, y el personaje pierde la memoria y enferma mentalmente. Asimismo, su cuerpo se descompone y se revuelca en los malos olores que expelen las calles. Vemos a un inquisidor degradado, con una figura grotesca que invita a la risa.

Entonces llegamos a la tercera clave de esta propuesta: la de lo cómico. Antes de precisar qué es lo cómico desde unas posturas filosóficas - como la de Bergson-, estéticas pictóricas —como la de Baudelaire- o estéticas literarias — como la de Bajtín—, presentamos a Juan de Mañozga como un personaje grotesco, degradado y motivo de burlas y risas. De tal modo, Los cortejos del diablo determina la vida del inquisidor en las tierras que tanto odia:

Y las brujas bajaron y alzaron el cuerpo monumental del Inquisidor por los aires impregnados de azufre, para conducirlo a Tolú, tierra del bálsamo, donde por toda la eternidad habría de besar a Buziraco —el espíritu de Luis Andrea- su salvohonor negro y hediondo (Espinosa, 2006: 222).

Es esta la condena irreversible a eso que tanto detesta: las brujas, los negros. Es una especie de diablo cojuelo que puede mirar desde los aires a esa Cartagena plácida, sensual y libre del 
oprobio del inquisidor, solo para irse a vivir con los hechiceros de Tolú y allí saborear las delicias de las negras que le ofrecen sexo.

\section{Juan de Mañozga y la Inquisición}

Para una aproximación a lo cómico de esta novela de Espinosa, es indispensable una breve exposición de lo que en el fondo ventila esta obra con el personaje histórico Juan de Mañozga. Para dicho fin, Espinosa se nutre de la Inquisición durante la época de la Colonia. Muestra los sacrificios a los que son sometidas toda clase de personas que van en contra de los dogmas y creencias impuestos por la fe católica. Al respecto, Álvarez (1997) hace un recorrido sobre la presencia del Tribunal Inquisitorial en Cartagena:

En líneas generales, bajo los conceptos de "herejes" o "herejías reformistas" he englobado preferentemente a los procesados por seguir doctrinas protestantes, luteranas, calvinistas y hugonotes - calificadas de esta manera por la Inquisición americana- que tenían unos principios semejantes; otras actitudes heréticas, poco definidas doctrinalmente, fueron también condenadas por la Inquisición (p. 139).

Estas líneas trazadas por la Iglesia católica tienen un componente político e ideológico: la extensión de sus dominios en términos del credo. Efectivamente, este es el fundamento del nacimiento de la Inquisición. En este mismo orden de ideas está la presencia del Barroco o arte de la Contrarreforma. Cartagena, sin embargo, es puerto negrero, y allí desemboca gran cantidad de hombres provenientes de Europa que traen consigo otras ideas y prácticas religiosas diferentes a las de Juan de Mañozga. De ahí que sea un imposible para él contener el arribo de estas, pues está de por medio el tráfico negrero, una fuente de enriquecimiento a través de la venta de esclavos. Álvarez (1997) señala puntualmente que se sataniza el hecho de ser extranjero, ya que este conlleva el rótulo de hereje:

Por esto, en América se creó pronto un clima de opinión de que extranjero - mercader o pirata-, hereje y enemigo político eran sinónimos. Ante posibles amenazas, la Corona prohibió el arribo de barcos extranjeros a los puertos americanos, salvo en caso del asiento y transporte de esclavos negros. Todo en vano, un número importante de testimonios llegó al Tribunal de la Inquisición denunciando prácticas y dichos heréticos (p. 140).

La Inquisición española divulga un manual de técnicas de tortura para hombres y mujeres denunciados ante el Santo Oficio por delitos contra la moral y las buenas costumbres. Fundados en Lima y México en 1579 y luego en Cartagena, en 1610, los tribunales de la Inquisición desarrollan una actividad persecutoria en el continente. Se recurre entonces a castigos y torturas como la horquilla del hereje, el collar de púas, el aplastacabezas, el desgarrador de senos, la guillotina y el garrote ${ }^{4}$, entre otros. El Santo Oficio se sirve de estos artefactos en contra de los esclavos negros e indígenas con el fin de evitar la sublevación contra el orden imperante, al igual que para reprender la práctica de creencias religiosas ajenas al credo católico.

\footnotetext{
${ }^{4}$ La información y las fotografías de estos castigos hacen parte del material recopilado durante una visita
} realizada por los autores al Palacio de la Inquisición en Cartagena, en marzo de 2014. 
Figura 1. Potro de tortura

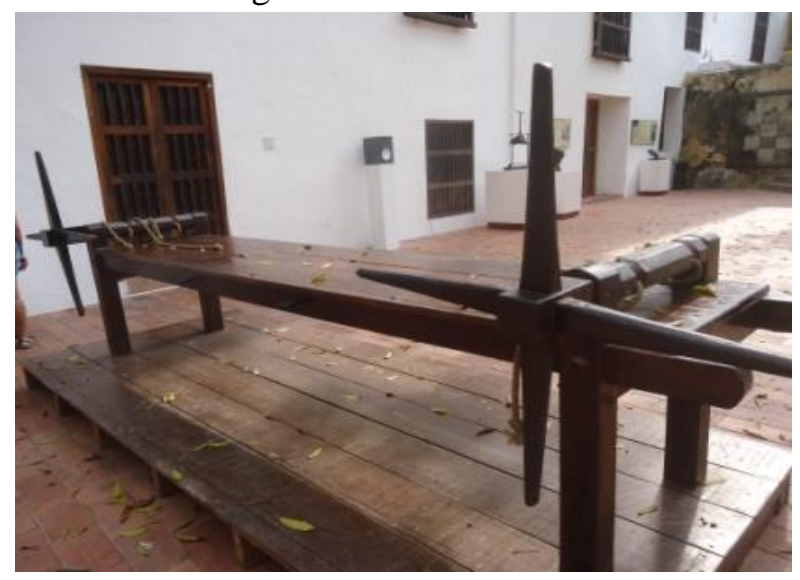

Fuente: elaboración propia.

En este sentido, la Iglesia se otorga el derecho de acabar con la vida de las personas que considera pecadoras por medio de torturas indignas. Una de ellas es la técnica del descuartizamiento, a partir del amarre de las extremidades inferiores y superiores a poleas tiradas desde las cuatro esquinas del potro (figura 1). Otra es la técnica del collar de púas, que se incrusta en el cuello y causa una muerte lenta y dolorosa (figura 2).

Figura 2. Collas de púas

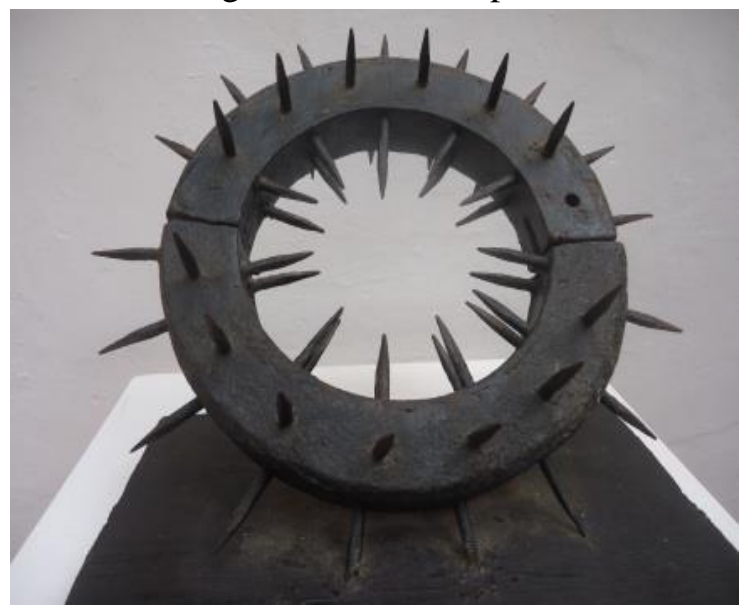

Fuente: elaboración propia.

A fin de evitar la muerte, los negros abandonan los cantos y las danzas, pues estos se consideran prácticas diabólicas; no importa que, en esencia, representen plegarias y adoraciones a sus lejanos dioses u orishas. Los negros buscan lugares lejanos a los ojos de la Inquisición. Se refugian en los palenques, y allá, en la libertad, pueden alabar y adorar de nuevo a sus dioses.

Otro aspecto de expiación es el del cuerpo desnudo del negro. Por caso, si una mujer sale entonces a la calle y un hombre la corteja, este acto merece, ante los ojos de la Inquisición, un castigo cruel hacia la mujer, ya que su conducta "seductora" atenta contra la moral. Los 
cortejos solo pueden hacerse por la ventana, ya que se considera que así se evitan la tentación y el pecado.

Una vez se conocen estos antecedentes, se entiende por qué Catalina de Alcántara desafía a Fernández de Amaya —alcaide de la Inquisición-, a Mañozga y al obispo Rosquillo de Córdova. De manera intencional, ella sale desnuda por las calles de Cartagena y se libra, pues, de la censura moral; desafía el poder eclesiástico. Para ello, se ampara en el poder económico que ostenta y sin el cual correría otra suerte (en la cita siguiente, el coche, el caballo árabe y los esclavos son indicios de dicho poderío económico). La desnudez no solo es aquí expresión de rebeldía, sino también de ironía y comicidad. La desnudez pone en tela de juicio la moral del inquisidor. Catalina de Alcántara desnuda su cuerpo y desnuda también el pensamiento de Mañozga, el inquisidor:

La viuda se encontraba, a las siete de la noche, desnuda sobre el caballo árabe que habría de transportarla a través de la ciudad y dispuesta a salir por la puerta cochera de su casa. Dos esclavos tenían a la bestia de la brida, y Catalina impartía las últimas instrucciones enderezadas a evitar accidentes enojosos a causa de la libido de los exaltados (Espinosa, 2006: 53).

Entre 1610 y 1921, en la ciudad de Cartagena, el Tribunal de Santo Oficio castiga a la mujer, considerada entonces apenas un objeto sexual y del pecado. Es preciso recordar que el rey Felipe II implanta en 1610 el Tribunal de Penas del Santo Oficio en esta ciudad portuaria, clave del tráfico negrero, tanto para el interior del continente como para otras ciudades del Caribe. La Inquisición funciona en Cartagena de Indias hasta el comienzo del proceso de independencia de esta ciudad, o sea, hasta el 11 de noviembre de 1811. Los representantes del Santo Oficio son expulsados de la ciudad, pero regresan en 1816, con el temible y sanguinario Pablo Morillo. Finalmente, estos hombres son desterrados en 1821, cuando Cartagena de Indias obtiene finalmente su independencia.

Retomamos el aspecto de la persecución de los negros. Otro de los castigos de entonces es el desgarrador de senos, que se usa para castigar a las mujeres culpadas de magia, herejía, brujería, blasfemia, adulterio o actos considerados por la Iglesia católica como libidinosos o que atentan contra la fe y la moral. Este desgarramiento se ejecuta con unas tenazas que, después de pasar por fuego, se incrustan en los senos de las víctimas.

Figura 3: Desgarrador de senos

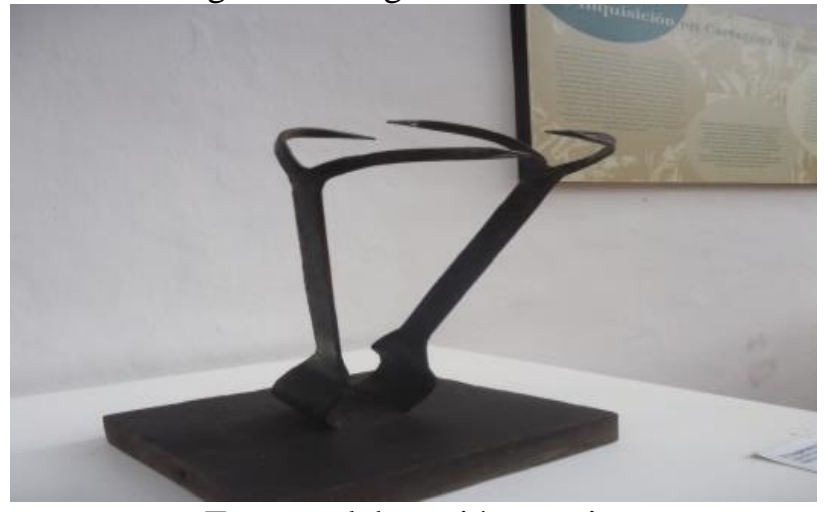

Fuente: elaboración propia. 
En Los cortejos del diablo se supone que Catalina es viuda de un alto personaje español, y ello avala aún más su altanería y actitud desafiante contra la moral. Pero ¿qué la hace a ella tomar esta decisión? Algunas de las respuestas conciernen al rumor y al correveidile entre el populacho y la Inquisición para lograr favores de Mañozga. Es el imperio de la opresión, el juicio, las penas y el castigo. La locura del inquisidor no es más que un artificio para acentuar la degradación de los miembros de la Iglesia y el imperio de torturas en la América negra. Por esto, Jarque (2000) señala que la convivencia entre gentes de diversa catadura no es entonces más que "meter al diablo en medio del remolino"s. En la Cartagena de la Colonia se viven los más dispares desenfrenos en todos los órdenes sociales. Convive allí la magia de los esclavos y de los indios con el ambiente de la Iglesia católica. De ahí que no extrañe, como señala Jarque, ver a brujas revoloteando sobre la cabeza del inquisidor Mañozga (p. $165)$.

Mas no solo se sienten los delirios de Mañozga, sino también la presencia de la cultura negra, con todo el poder de su música y de su danza, que evocan sus ancestros religiosos y su pasado africano. La imponencia de las iglesias es solo, para los esclavos, decoración y ostentación del colono, pero a pocas horas de la ciudad se vive África en su plenitud, en el refugio del Palenque. Cada esquina de la ciudad es una muestra de la imposición de una cultura española, aunque fuera del llamado "corralito de piedra" se vive la verdadera ciudad de los antepasados: miseria, engaño e ilusión, opresión y violencia, míseros avales para retar la violencia e indiferencia del poderoso ${ }^{6}$. En este sentido, la figura del inquisidor Juan de Mañozga representa una época de dolor, de sufrimiento, de despojo. Una época de dominación y miseria caracterizada por la imposición de la fe católica.

\section{Los cortejos del diablo, recreación del pasado inquisitorial}

Con el fin de profundizar en esta figura inquisitorial, en este artículo analizamos la novela Los cortejos del diablo a partir de una visión cómica que propicia el encuentro cultural e ideológico entre el blanco y el negro a través de la Iglesia católica, y la manera en que Espinosa teje los hilos de la historia a través de la figura del inquisidor durante un periodo de la Colonia en Cartagena de Indias.

Desde el título de esta novela ya se insinúan los requiebros de lo cómico, pues se sabe que "cortejo" no solo significa "galantear", sino también "acompañar con agrado a alguien". Pues bien, ¿de cuál compañía se puede hablar en esta novela? La respuesta inquieta en su contradicción, ya que al inquisidor lo acompañan, en su mortificación y delirio, las brujas y el demonio. Dicha presencia determina que el modo de pensamiento y comportamiento del inquisidor rebaje su conducta hasta la locura, y que con ella se produzca la degradación de su investidura inquisitorial. Sin embargo, lo que más inquieta a Juan de Mañozga es la incapacidad de asimilar esa realidad mágica desbordante bajo el imperio de la brujería, la hechicería y lo demoniaco, condiciones inherentes a la idiosincrasia de los negros y los indios. Estas prácticas complejas no hacen parte del pensamiento y las formas de vida del

\footnotetext{
${ }^{5}$ Este mismo texto aparece en el epígrafe de la novela Gran Sertón: veredas, de João Guimarães Rosa.

${ }^{6}$ Este contexto lo recrea Burgos Cantor en su volumen de cuentos De gozos y desvelos (1982), con sus personajes negros, sumidos en la periferia del dolor, ilusionados en las canciones que les hablan sobre la mujer, o en la fantasía de la opulencia a través de los golpes en el boxeo. 
colono; por el contrario, su comportamiento está regido por las normas de la moral, de las buenas maneras y costumbres, tanto en el hogar como en la calle.

A propósito, Ceballos (1995) señala que la brujería es la antítesis del cristiano. El color blanco se asocia con el cristianismo, en tanto el color negro se asocia con la brujería, en contraste de las buenas costumbres de la sociedad europea. Todo lo del negro hiede a brujería, se relaciona con lo demoniaco (p. 152). Indudablemente, la concepción sobre la brujería en ese mundo colonial es propicia en Cartagena, una ciudad-puerto ideal para el encuentro de aventureros, de gente ambiciosa y sin escrúpulos. En esta ciudad confluyen indios, negros africanos, mercaderes de las islas menores del Caribe, portugueses buscadores de oro, marineros y gentes del bajo mundo español, especialmente sevillanos. Con toda esta mezcla cultural, Cartagena se llena también de pícaros, ladrones, timadores y asaltantes.

Lo mismo sucede con los prisioneros de las galeras provenientes de una España incapaz de asumir los costos elevados de la manutención de los reos en las cárceles. Por este motivo, la Corona española comprueba que el envío a las nuevas colonias es una opción viable en la solución de ese problema; de ahí que traigan hombres salidos de las cárceles, en su mayoría ${ }^{7}$. Ahora bien, en esta encrucijada cultural, social e ideológica toman asiento la Iglesia católica y la Inquisición para contrarrestar ese mundo ingenioso de los negros, pues estos asumen la ortodoxia católica y hacen de ella un catolicismo popular conveniente a las apariencias del credo de los blancos. En Colombia esta situación no es tan evidente, pero, si nos remontamos a Cuba, podemos ver más claro el sincretismo religioso en imágenes como la de Changó, dios del fuego, del trueno y de la virilidad, de la cultura lucumí, quien tiene su equivalencia en el catolicismo en la imagen de santa Bárbara.

En efecto, en el nuevo mundo religioso estos hombres se ven obligados a asimilar las concepciones del mundo católico, así como otras formas de pensamiento. Por tal motivo, en Cartagena el mundo religioso cristiano asume formas sincréticas con la cultura de los africanos, así como con el protestantismo de piratas y corsarios, y finalmente con la Ilustración (Roux-López, 2003: 13). Se puede establecer aquí una relación estrecha con el escenario de la novela Los cortejos del diablo y los personajes que allí confluyen, con los que Espinosa logra la configuración de un mundo novelesco en torno a la Inquisición y a los representantes de la Iglesia católica.

Se conoce que en aquella época Cartagena es el enclave de puerto negrero más importante de América del Sur, y desde su fundación, en 1533, el puerto de más movilidad en el tráfico esclavista. Asimismo, representa un punto de referencia para la entrada al territorio a través del río Magdalena. Al respecto nacen dos temores: el primero, concerniente a la fuerte influencia de los judíos y su religión; el segundo, asociado con la práctica de brujería y hechicería, actos relacionados con su paganismo religioso. El colono no concibe al indígena o al negro como diferente, sino como inferior. Esta situación se expresa claramente en la imposibilidad de aceptar, de entender o de asimilar la adoración por parte de los indios hacia

\footnotetext{
${ }^{7}$ De esto dan buena cuenta la literatura picaresca y la novela cervantina, como es el caso de Rinconete $y$ Cortadillo y del capítulo XXII de la primera parte de El Quijote, en donde el de la Triste Figura libera a los reos que van encadenados y, con ellos, a su jefe, Ginés de Pasamonte. 
las montañas, los ríos, el Sol y la Luna, o las prácticas religiosas de los negros asociadas con el baile y el sexo. Todo esto se reduce a paganismo por parte del colono.

Ahora bien, esta encrucijada cultural propicia que Cartagena sea asiento del Tribunal de Inquisición, fundado por Felipe III el 25 de febrero de 1610. Los fines primordiales de la Inquisición son el dogma, la moral y las buenas costumbres, esto es, acabar con las prácticas de brujería, las expresiones del protestantismo y las costumbres de los judíos. Para tal fin, allí están los primeros inquisidores, Mateo de Salcedo y Juan de Mañozga. Hacemos referencia a estos hechos debido a que es de este universo de coerción y represión del que se aprovecha Espinosa para hacer del pasado colonial de Cartagena una puesta en escena de lo cómico a través de Juan de Mañozga.

\section{La presencia de lo cómico}

Es importante aclarar el término "cómico" y su función en la novela de Espinosa. Para Baudelaire (1963), lo cómico se asocia con la risa. Su esencia es una muestra de las flaquezas del espíritu. De tal manera, Mañozga asume su papel de inquisidor y expone sus debilidades, tanto físicas como mentales. Esas flaquezas aumentan en la medida en que el sexo de las negras lo tienta y en que el credo de los negros lo vence a través de las prácticas de brujería. Su espíritu no está acostumbrado a esas expresiones culturales y religiosas, pues su educación tiene unas sutilezas dadas en la fe, que no en la práctica.

En este orden de ideas, cobran valor los planteamientos de Bergson (1986), para quien lo cómico está centrado en lo humano. No existe fuera de lo humano algo cómico, y para que sea cómico, debe responder a prejuicios de asociación; por ejemplo: Mañozga asocia los espacios de los negros, sus prácticas religiosas, sus olores y sus formas de vida con lo demoniaco o brujeril. La comicidad de Mañozga está en el desconocimiento que tiene de sí mismo (Bergson analiza este caso en el Quijote).

De la misma manera, para Bajtín (1974), uno de los componentes de lo cómico es lo grotesco. El cuerpo es el referente de esta idea desde la degradación paródica: tal como un Sancho Panza, nos muestra a Mañozga con su vientre abultado o, como el Quijote, diciendo incoherencias propias de su locura. Asimismo, están las sandeces como sistemas significantes de su degradación y locura. Hay en Mañozga unas imágenes de la cultura cómica popular gracias a las creencias en brujas y demonios con las que atrofia su pensamiento

González Mojica (1992) señala que Los cortejos del diablo se narra desde lo cómico y lo satírico. En la novela se observa la presencia adaptada de los sainetes y los entremeses del Siglo de Oro español (p. 122). Por otra parte, en función de la representación atormentada del inquisidor, Victoria (1958) señala que "lo cómico es un no tomar algo en serio, una desvalorización". Lo cómico es, continúa el crítico, "una toma de posición ante una valoración negativa del ser, con respecto a un objeto ideal o real" (p. 52). Por consiguiente, en Los cortejos del diablo lo cómico se presenta desde la perspectiva de esos personajes venidos de Europa provistos de una fuerte concepción del mal, es decir, todo el ser anímico determinante en el encuentro de diversas religiones, en un espacio ajeno y complejo de la religión africana en todas sus variantes. 
Lo cómico, como una valoración negativa de la religión del negro, es el mal engendrado en la conciencia de este o, por decirlo con Kant (2001), toda mala acción tiene que considerarse como si el hombre hubiese incurrido en ella a partir de la inocencia (p. 61). En este sentido, podemos afirmar que en Los cortejos del diablo tiene lugar lo racional enfrentado al estado de inocencia, esto es, la presencia del blanco inquisidor y sus acciones oprobiosas para la imposición de la religión en contraposición al negro, que tiene toda una gama de expresiones, tanto ideológicas como culturales, de su lejana África, pertenecientes a un estado de inocencia. Estas dos posiciones hacen que en esta novela se presenten muchas situaciones cómicas, pues para Juan de Mañozga es imposible entender ese mundo convulso y complejo de la Cartagena negra. Es en este proceso dialógico que toma fuerza lo cómico-humorístico en Los cortejos del diablo. Tal como vemos al comienzo de la novela, encontramos un personaje completamente sumido en los desvaríos y en la locura como expresiones de su incapacidad. Es este el tono humorístico y cómico de la narración en clave de soliloquio:

¡No hay en el campo sino pedruscos!, ruge la jácara cándida y, desde el mirador del Santo Oficio, el anciano Juan de Mañozga oía aletear las parejas de brujas cuyos balidos de chivato confirmaban, a la mente senil del Inquisidor, sus calenturientas presunciones: aquellos extraños seres bailaban de noche alrededor de un cabrón, le besaban el culo almizcloso, recibían su helado semen y luego lo diseminaban, volando con candelillas diabólicas en las manos sobre el haz de la tierra. ¡Esto es lo que me he ganado por venirme a las Indias, esta Iglesia de alzados y de follones! ¡Es lo que mi codicia me ha deparado, zopenco de mí, que un día me vi en sueños confesor de sus muy católicas majestades! ¡Oveja y abeja y piedra que trebeja y péndola tras oreja y partes en la igreja deseaba a su hijo la vieja! ;Zopenco, palurdo, mentecato de mí, que me he labrado mi propio infierno! (Espinosa, 2006: 17).

Las reflexiones del inquisidor anuncian su estado demencial, producto de sus invenciones brujeriles y demoniacas. "Ruge la jácara cándida", es decir, la danza alegre que cuenta la vida de negros y blancos; la música para cantar y bailar esas danzas cadenciosas y lujuriosas de los negros. "¡Zopenco!”, exclama el anciano Mañozga, por caer en estas tierras, por la avaricia, por la sed de oro, por los rumores de los personajes que lo visitan para denunciar la presencia de brujas y de sus tratos con el diablo.

Mañozga solo oye los balidos del chivato, los balidos de ese fantasma en forma de chivo que lanza llamas por los ojos: el demonio que ronda la mente senil del anciano. La Iglesia - "igreja", en su desusado vocablo - ronda por la mente del inquisidor. Palurdo, grosero, es el fin de este representante de la Iglesia y de la Inquisición en tierras de paganos. Palurdo como expresión de su degradación; grosero en esas calles de oprobio, maledicencia y palabras de gente rala. Tiene aquí lugar la degradación del personaje desde la amplia dimensión cómica.

Esta es la primera aproximación a la novela de Espinosa a partir de las exclamaciones de Mañozga, pues en ellas aparece la naturaleza de los problemas axiológicos que presuponen; valores que expresan su condición alienada del catolicismo. Por esta razón, lo cómico del encierro no establece distinciones entre lo real y lo empírico. Lo real es la vida del negro, mientras que lo empírico es la percepción de las conductas de este. Lo cómico se da desde el juego, la trampa que le tienden sus enemigos, desde la antinomia en su papel de inquisidor y 
desde la oposición de los valores a partir de la presencia de la mujer, la seducción, el sexo y la lujuria. Lo cómico se percibe en el contraste de las representaciones ideológicas y en las comparaciones entre la fe y el ritual.

La imagen cómica en Los cortejos del diablo tiene que ver con el cuerpo, y es aquí donde asume validez tal aproximación al personaje degradado del inquisidor:

Mañozga, con unos calzones angostos que le cubrían desde la cintura hasta el arranque de las piernas (cuyas costuras daban la impresión de estar haciéndole llagas) y un jubón echado sobre los hombros, iba desvariando de un lado a otro del edificio, repartiendo órdenes impertinentes y estorbando dondequiera que algo importante se hacía (Espinosa, 2006: 77).

Mañozga, al descubierto, ante la mirada sentenciosa de sus detractores, muestra no solo su cuerpo macilento, sino la locura; y lo más degradante es el sentido de autoridad rebajado a la más deplorable condición, pues antes es un personaje imponente, de referencia en la plaza pública cuando lee los autos de fe, y ahora estorba.

En tal sentido, retomamos a Bajtín, quien establece tres categorías para la condición de lo cómico. La primera de ellas es lo cómico bufonesco. En este caso Mañozga es una especie de personaje bufonesco en cuanto su función coercitiva no asume la dimensión opresora, sino todo lo contrario: produce risa, tal como se evidencia en el diálogo entre Fray Cristóbal y el Inquisidor: "-Acaba, leche, ¿y qué demonios dicen? -Dicen que el Santo Oficio les ha cogido miedo a los brujos" (Espinosa, 2006: 59).

La segunda categoría es lo cómico burlesco, que se define en los contrastes de las cosas elevadas que terminan por cansar y rebajarse. Los cortejos, precisamente, tienen esa finalidad: el rebajamiento o degradación de la autoridad. "Mañozga avanzaba sin rechistar. Una rasquiña empezaba a carcomerle el pecho. ¡Perdidos los poderes! Pensaba en los brujos y pensaba también en el Adelantado" (Espinosa, 2006: 81).

La última categoría, lo cómico grotesco, nos permite definir la configuración de Juan Mañozga en ese espíritu degradado que le carcome sus formas de pensamiento: el movimiento del cuerpo proviene de adentro hacia afuera. En la medida en que se rebaja mentalmente, también su cuerpo se degrada, en su encierro en el Palacio Inquisitorial, en su descenso para que varios legos dominicos, cogidos por sorpresa, barran la sala del tribunal, extrañamente poblada de ratas y cucarachas. Esta imagen anuncia el ocaso del viejo inquisidor: antes con sus mazmorras llenas de reos; ahora plagadas de basuras y en el abandono. El desmoronamiento del tribunal funciona como metáfora del declive del protagonista con el ocaso espiritual y existencial del Inquisidor:

Mañozga cruzó entre la muchedumbre con el jubón que casi se le caía de un hombro, arrastrando las piernas y dando a su paso una sensación de desamparo y decrepitud. Se oyó un murmullo indefinible. Los que no lo conocían, interrogaban a los otros, intrigados por esta aparición fantasmal de un hombre a quien suponían en el apogeo de la sanguinaria majestad (Espinosa, 2006: 77). 
Ahora bien, lo cómico determina ese ambiente complejo de Cartagena en donde se tejen historias y rumores entre la pareja conformada por el inquisidor Mañozga y Catalina. Ante estos rumores, en sus soliloquios Mañozga se defiende culpando a otros:

Cerraron la celda y Mañozga oyó claramente cómo una bruja luchaba con la rejilla del tragaluz, bregando por entrar al palacio. Ah, cuánto amargáis mi vejez. Y pensar que todas desfilasteis por la polla de Fernández de Amaya, que no por la mía, como lo aseguran las malas lenguas. Yo prefería a las ricas dominicas que aspiran a unirse a algún encomendero (Espinosa, 2006: 140).

La Inquisición, el inquisidor, la mujer, el sexo y la religión convergen en los recuerdos de Juan de Mañozga. Sexo entre religiosos, entre los impositores de la ley, de una ley coercitiva con la promiscuidad sexual, y ellos, los transgresores. De ahí que sea muy significativo el encierro del inquisidor, pues desde adentro del escenario fundamenta sus cavilaciones. Ahora, como un hecho cómico, Mañozga está metido en la misma cárcel donde él encierra a brujos y brujas. El inquisidor, en el encierro, cava su locura, que es la más clara expresión de su decadencia. Sumado a esto, Mañozga mira hacia dentro de su cuerpo y encuentra su mente poblada de lo sobrenatural, percibe los vuelos nocturnos de las brujas y de los poseídos, siente los aquelarres mágicos y la presencia el semen del diablo esparcido por los oscuros laberintos de las mazmorras.

El inquisidor suelta expresiones escatológicas e invita a Buziraco para que tiente a los célibes y posea a las monjas renuentes al sexo; asimismo, reflexiona sobre la descomposición de la Iglesia en esta ciudad portuaria. En este encuentro la novela asume un sentido de comparsa, en donde este personaje convive en medio de la juerga, el sexo y la persecución religiosa. Silva (2013), a propósito, advierte que con Mañozga se personifican la crisis y el anuncio del cambio cultural y político. El declive de Mañozga, continúa Silva, es resultado de que el espíritu libertario de los esclavos y los cimarrones se imponga sobre la religión católica y los valores de la Contrarreforma (p. 40).

El inquisidor no es consciente ni asume el cambio social e ideológico que transita por las calles de Cartagena, y esta decadencia del poder inquisitorial incide en el declive de la Iglesia: "es el Santo Oficio sin oficio", como se afirma en la novela. De ahí que el encierro del inquisidor sea la imagen del deterioro, porque desde afuera aparecen unos personajes marginales, como el judío Lorenzo Spinoza, el barbero Orestes Cariñena y la bruja Rosaura García, que se burlan de la autoridad de la Inquisición; asimismo, Pedro Claver y el obispo Fray Cristóbal Pérez de Lazarraga demuestran el anacronismo de la persecución inquisitorial. Más al fondo, los esclavos con sus comparsas ofrecen ese mundo de miseria, esos estados de opresión y esos ánimos espirituales para conservar y mantener viva la cultura de su lejana África. La opresión religiosa e ideológica ha llegado para ellos a su fin.

Germán Espinosa logra con esta novela cimentar las relaciones discursivas entre lo ficcional y lo histórico a partir de ese personaje célebre en la historia de Cartagena durante la Inquisición. El escritor no recaba sobre los suplicios a los que son sometidos los herejes, sino que centra su atención novelística en la degradación del personaje y, desde lo cómico, muestra otra faceta de esos personajes reales que llegan a América y dejan un aura de su incompetencia, gracias al poder usurpado a los aborígenes. 


\section{Referencias}

Álvarez, F. (1997). Herejes ante la Inquisición de Cartagena de Indias. Revista de la Inquisición, 6, 239-265.

Bajtín, M. (1974). La cultura popular en la Edad Media y el Renacimiento. Barcelona: Barral Editores.

Baudelaire, C. (1963). De la esencia de la risa y, en general, de lo cómico en las artes plásticas. En C. Baudelaire Obras, 596-648. México: Ediciones Aguilar.

Bergson, H. (1986). La risa. México: Editorial Porrúa.

Blázquez, J. (1994). Brujas e inquisidores en la América colonial (1569.1820). Revista Espacio, Tiempo y Forma, serie IV, 71-98. Madrid: UNED.

Ceballos, G. D. L. (1995). Hechicería, brujería e Inquisición en el Nuevo Reino de Granada: Un duelo de imaginarios. Medellín: Ed. Universidad Nacional de Colombia.

Espinosa, G. (2006). Novelas del poder y de la infamia. Bogotá: Alfaguara.

González de Mojica, S. (1992). Los cortejos del diablo y La tejedora de coronas. Una lectura del imaginario político. En C. R. Figueroa et al. Seis estudios sobre La tejedora de coronas de Germán Espinosa, 119-141. Bogotá: Fundación Fumio Ito, Pontificia Universidad Javeriana.

Kant, I. (2001). La religión dentro de los límites de la mera razón. Madrid: Alianza Editorial.

Navarrete, M. C. (2017). Una noche de luces y festejo en Cartagena de Indias, 1690. Fronteras de la Historia, 22(1), 136-163.

Rosas, R. M. (2010). Los negros esclavos y el Tribunal de la Santa Inquisición en Lima y en Cartagena de Indias (1570- 1650). Piura: Universidad de Piura.

Roux-López, R. (2003). Cartagena y los pecados de Indias. En M. Guicharnaurd-Tollis (Ed.). El Caribe. Elementos para una historia de los puertos, 13-25. Toulouse: Le Mirail, Université de Toulouse.

Silva, J. M. (2000). Entre el significado y la fantasía. En A. Espinosa (Ed.). Espinosa oral (pp. 133154). Barranquilla: Fondo Editorial de la Universidad del Atlántico.

Silva Rodríguez, M. (2013). Espiritualidad negra, religiosidad y mito en Los cortejos del diablo de Germán Espinosa. Estudios de Literatura Colombiana, (32), 39-59.

Victoria, M. (1958). Ensayo preliminar sobre lo cómico. Buenos Aires: Editorial Losada.

Jarque, Y. E. (2000). Un escritor fascinado por las sectas esotéricas. En Castillo Mier (Coord.). Espinosa oral. Barranquilla: Fondo de Publicaciones Universidad del Atlántico. 